\title{
Growth-rate-dependent synthesis of K99 fimbrial subunits is regulated at the level of transcription
}

\author{
Marjan W. van der Woude, ${ }^{*}$ Patricia A. Arts, Douwe Bakker, Henk W. van Verseveld \\ and FRITS K. DE GRAAF
}

Department of Microbiology, Biological Laboratory, Vrije Universiteit, de Boelelaan 1087, 1081 HV Amsterdam, The Netherlands

(Received 23 October 1989; revised 21 December 1989; accepted 15 January 1990)

\begin{abstract}
Increase in the production of the fimbrial adhesin $\mathrm{K} 99$ by enterotoxigenic Escherichia coli in continuous cultures at specific growth rates above $0.25 \mathrm{~h}^{-1}$ was shown to be independent of the nature of the growth-limiting nutrient. The correlation between specific growth rate and $\mathrm{K} 99$ production was also found to be independent of the copy number of the K99 operon. Introduction of additional copies of the K99 regulatory region did not affect growth-ratedependent $\mathrm{K} 99$ production in wild-type strains, indicating that no hypothetical regulatory host factor is titrated by the K99 regulatory region. Regulation at the transcriptional level was measured with galactokinase gene fusions. The transcription of the fimbrial subunit gene increased with an increase in specific growth rate. This growth-ratedependent transcription was found to originate from the strong promoter $P_{A}$. Transcription originating from the weaker promoter $P_{B}$ was independent of growth rate. The results indicated that transcriptional regulation at $P_{A}$ is involved in the growth-rate-dependent regulation of K99 production.
\end{abstract}

\section{Introduction}

An important step in infections by enterotoxigenic Escherichia coli is the adhesion of the bacteria to the intestinal epithelial cells of their hosts. Fimbriae play an important role in this adhesion. K99 fimbriae produced by enterotoxigenic $E$. coli mediate adhesion to bovine, ovine and porcine small intestines (Gaastra \& De Graaf, 1982). The available knowledge on the molecular organization of the K99 operon and on the effects of specific growth rate, $\mathrm{pH}$ and temperature on the production of $\mathrm{K} 99$ fimbriae enabled us to examine the molecular mechanisms underlying physiological regulation

The eight genes $(\operatorname{fan} A-H)$ encoding the proteins necessary for expression of $\mathrm{K} 99$ fimbriae have been cloned and sequenced (Fig. 1a) (De Graaf et al., 1984; Roosendaal \& De Graaf, 1989; Roosendaal et al., 1984, $1987 a, b)$. They are organized in a single operon. fan $A$ and $\operatorname{fan} B$ encode two regulatory proteins; fan $C$ encodes the major fimbrial subunit; fan $D$ encodes a polypeptide located in the outer membrane involved in the export of the fimbrial subunits and in the anchorage of the fimbriae in the outer membrane; fan $E$ encodes a

Abbreviation: $\mu$, specific growth rate. periplasmic carrier protein that binds fimbrial subunits and delivers them to the FanD protein; fanF to fanH encode minor fimbrial components involved in $\mathrm{K} 99$ biosynthesis. Analysis of the transcriptional organization of the operon revealed two promoters, $\mathrm{P}_{\mathrm{A}}$ and $\mathrm{P}_{\mathrm{B}}$, located upstream from $\operatorname{fan} A$ and $\operatorname{fan} B$, respectively (Roosendaal et al., 1987a). Factor-dependent terminators are located between $\operatorname{fan} A$ and $\operatorname{fan} B\left(\mathrm{~T}_{1}\right)$ and between $\operatorname{fan} B$ and $\operatorname{fan} C\left(\mathrm{~T}_{2}\right)$, and a strong rho-independent terminator was found between the structural genes $\operatorname{fan} C$ and $\operatorname{fan} D\left(\mathrm{~T}_{3}\right)$. FanA and FanB have been shown to function in trans as anti-terminators of transcription (Roosendaal et al., 1989).

The expression of $\mathrm{K} 99$ fimbriae is regulated by environmental conditions. Low temperature, low $\mathrm{pH}$ of the medium or the presence of alanine represses the production of K99 fimbriae (De Graaf et al., 1980a, $c$; Girardeau et al., 1982; Van Verseveld et al., 1985). K99 synthesis is also dependent on the specific growth rate. No production takes place at growth rates below 0.25 $\mathrm{h}^{-1}$, but the production increases sharply at higher growth rates (Van Verseveld et al., 1985). The molecular mechanisms involved in the regulation of these phenomena are unknown.

Regulation of $\mathrm{K} 99$ synthesis might take place at the transcriptional level, involving the two promoters and/or 


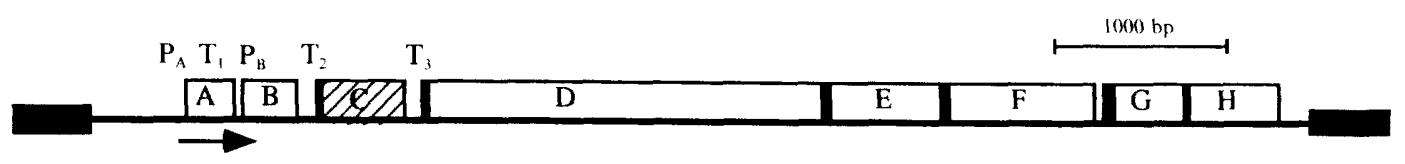

(b)
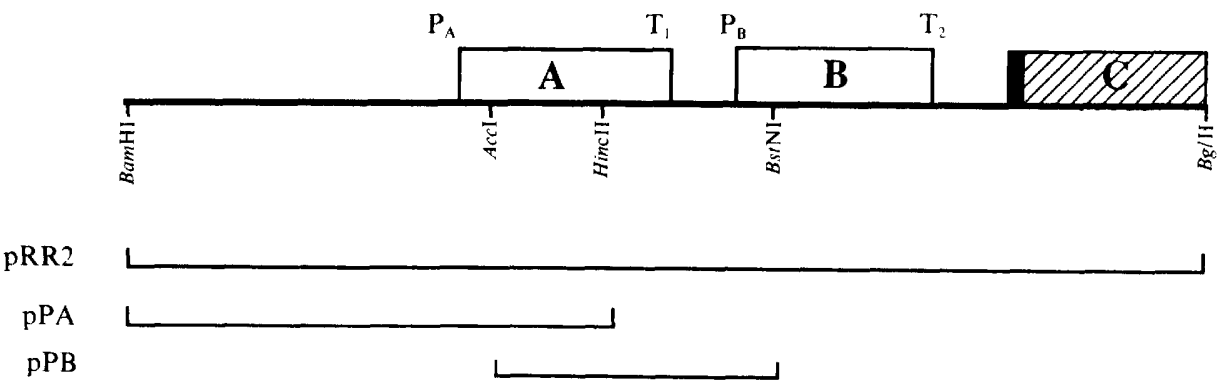

Fig. 1. (a) Genetic map of the K99 operon. P, promoter; T, terminator of transcription; A-H, fanA-fanH; the subunit gene is shaded and dark blocks indicate signal peptides. The arrow indicates the direction of transcription. (b) The regulatory region and the fragments cloned into the galK fusion vector for construction of pRR2, pPA and pPB, shown in detail (after Roosendaal et al., 1989).

the terminators, or by post-transcriptional regulation of the gene transcripts. In this study we used gene fusion techniques to investigate whether a transcriptional regulatory mechanism is involved in the growth-ratedependent control of the production of fimbriae. The transcriptional activity of the two promoters was measured at different growth rates and compared to the transcription of the fimbrial subunit gene. We also examined the effect on production of fimbriae of the presence of multiple copies of the regulatory region.

\section{Methods}

Bacterial strains and plasmids. E. coli F18, serotype O101: $\mathrm{K}^{-}: \mathrm{K} 99: \mathrm{F} 41$, was used as the wild-type, K99-producing strain. This strain carries the $\mathrm{K} 99$ operon on a low-copy-number conjugative plasmid. E. coli strain K12 C600 galK was used as a host for the galactokinase fusion plasmids pKO-l, pKG1800 (McKenney et al., 1981), pKC86 (Chak \& James, 1985) and their derivatives pPA, pPB and pRR2 (Roosendaal et al., 1989), unless mentioned otherwise. Fig. $1(b)$ shows the genetic map of the regulatory region of the K 99 operon and the fragments cloned into the vector $\mathrm{pKO}-1$ to obtain plasmids pRR2, pPA and pPB (Roosendaal et al., 1989). E coli K 12 C600 strain F87 ( $\lambda^{-}$, tonA21 thr-1 leu-6 thi-1 supE44 lac Y), was used as a host for the K99-encoding plasmid pJN99. In the latter plasmid the BamHI fragment of pFK 99 containing the K99 operon (Van Embden et al.. 1980; De Graaf et al., 1984) has been inserted into the BamHI site of the vector $\mathrm{pACYC} 184$

Growth conditions and media. Strain F18 was grown on minimal medium containing, per litre: $\mathrm{KH}_{2} \mathrm{PO}_{4}, 4.5 \mathrm{~g} ; \mathrm{K}_{2} \mathrm{HPO}_{4} \cdot 2 \mathrm{H}_{2} \mathrm{O}, 5 \cdot 7 \mathrm{~g}$; $\mathrm{NH}_{4} \mathrm{Cl}, 2 \cdot 0 \mathrm{~g} ; \mathrm{MgSO}_{4} \cdot 7 \mathrm{H}_{2} \mathrm{O}, 0.2 \mathrm{~g} ; \mathrm{FeSO}_{4} .7 \mathrm{H}_{2} \mathrm{O}, 5 \mathrm{mg}$; citric acid, 5 $\mathrm{mg}$ : $\mathrm{CaCl}_{2}, 11 \mathrm{mg}$; and glucose monohydrate, $1.98 \mathrm{~g}$, as carbon and energy source for batch cultures and chemostat cultures with glucose as the growth-limiting nutrient. For chemostat cultures with sulphate as growth-limiting nutrient $\mathrm{FeSO}_{4} \cdot 7 \mathrm{H}_{2} \mathrm{O}$ was substituted by $3.6 \mathrm{mg}$ $\mathrm{FeCl}_{2} \cdot \mathrm{H}_{2} \mathrm{O}$, and $5.95 \mathrm{~g}$ glucose monohydrate and $18.5 \mathrm{mg}$ $\mathrm{MgSO}_{4} \cdot 7 \mathrm{H}_{2} \mathrm{O}$ per litre were added. For strain $\mathrm{F} 18$ transformed with pRR2, ampicillin was added to a final concentration of $200 \mu \mathrm{g} \mathrm{ml}^{-1}$.
The galK strain harbouring derivatives of pKO-1 or pGK1800 was grown in the same medium as above except that only $1 \mathrm{~g}$ glucose was added, and the medium was supplemented with $0.5 \mathrm{~g}$ yeast extract $1^{-1}$, $0.5 \mathrm{~g}$ Casamino acids $\mathrm{l}^{-1}$ and $300 \mu \mathrm{g}$ ampicillin $\mathrm{ml}^{-1}$. Strain F87 harbouring pJN99 was cultured as for the galK strain except that ampicillin was omitted and chloramphenicol $\left(70 \mu \mathrm{g} \mathrm{ml}^{-1}\right)$ was added.

Bacteria were grown as continuous cultures in chemostat mode at $37^{\circ} \mathrm{C}$ and pH 7.2 (Stouthamer \& Bettenhausen, 1975), or as batch cultures on a shaking platform as mentioned. Cultures were in steady state after a minimum of six generation times at constant biomass concentration. Biomass concentrations were measured as described before (Van Verseveld et al., 1985)

Enzyme assays. Samples were taken from steady-state cultures and immediately frozen at $-20^{\circ} \mathrm{C}$. Cell extracts for the enzyme assays were prepared by sonicating culture samples for $2 \mathrm{~min}$ in $20 \mathrm{~s}$ pulses with intermittent cooling. The galactokinase assay was performed as described by McKenney et al. (1981). Galactokinase units are expressed as $\mathrm{nmol}$ galactose phosphorylated per min per $\mathrm{ml}$ of culture with a turbidity $\left(\mathrm{OD}_{660}\right)$ of $1 \cdot 0 . \beta$-Lactamase activity was determined in the same cell extract as galactokinase activity. The enzyme activity was determined in $100 \mathrm{~mm}$-potassium phosphate buffer $(\mathrm{pH} \mathrm{7.5)}$ by measuring the difference in absorbance of nitrocefin (compound 87/312) at $486 \mathrm{~nm}$ (O'Callaghan et al., 1972). $\beta$-Lactamase units are expressed as $\Delta A_{486}$ per min per ml culture (OD ${ }_{660}$ of $\left.1 \cdot 0\right)$. Assays were performed in duplicate.

Determination of plasmid concentration. The plasmid content of cells harbouring plasmids with an ampicillin resistance marker was determined by measuring $\beta$-lactamase activity as described above. The enzyme activity gives an estimate of the varying content of plasmid at different growth rates (Klotsky \& Schwartz, 1987). For determining the content of pJN99, plasmid DNA from a standard amount of cells was isolated by the small-scale extraction procedure of Birnboim and Doly as described by Maniatis et al. (1982), using standardized volumes throughout the extraction. Plasmid DNA was loaded onto agarose gels in triplicate and the gels were run according to standard methods (Maniatis et al., 1982). The DNA band intensity was determined by densitometer scanning of photograph negatives of the agarose gels with a laser scanner (LKB Ultroscan 2202). Intensities were taken as a measure of the plasmid content of the culture

Determination of $K 99$ production. $\mathrm{K} 99$ production was determined by enzyme-linked immunosorbent assay (ELISA) of cells resuspended in 
phosphate-buffered saline (100 mM-sodium phosphate buffer, $\mathrm{pH} 7 \cdot 0$, $0.9 \% \mathrm{NaCl}$ ) to an $\mathrm{OD}_{660}$ of 0.5 (De Graaf et al., 1980b). The K99 specific antisera and conjugate were a generous gift of F. G. van Zijderveld, Central Veterinary Institute, Lelystad, The Netherlands.

\section{Results}

\section{Influence of growth limitation by an anabolic or a} catabolic nutrient

The effect of the nature of the growth-limiting nutrient on the regulation of the production of $\mathrm{K} 99$ fimbriae was investigated. Previous results have shown that the production of $\mathrm{K} 99$ fimbriae takes place at specific growth rates $(\mu)$ above approximately $0.25 \mathrm{~h}^{-1}$ and increases with increasing growth rates in continuous cultures with glucose as the growth-limiting nutrient (Van Verseveld et al., 1985). Glucose limitation is of a catabolic nature. The effect of only anabolic limitation was tested by growing the wild-type, K99-producing $E$. coli strain F18 in a continuous culture with sulphate as the growth-limiting nutrient (Fig. 2). Under sulphatelimited conditions K99 fimbriae were produced at $\mu$ values above $0.25 \mathrm{~h}^{-1}$, and production increased with increasing values of $\mu$. The production pattern and the level of production were similar to those found for glucose-limited growth. In the experiments described below continuous cultures growing with glucose as the growth-limiting nutrient were used.

Regulation of $K 99$ production in cells with multiple copies of the K99 operon

Previously, it was shown that the production of K99 fimbriae by a $\mathrm{K}^{2} 9^{+}$wild-type strain increased two- to four-fold after introduction of a multi-copy plasmid containing the K99 operon (Van Embden et al., 1980). This suggests a gene dosage effect that may contribute to growth-rate-dependent $\mathrm{K} 99$ production

The effect of the presence of the K99 operon in multiple copies on growth-rate-dependent synthesis was examined by determining the production of $\mathrm{K} 99$ fimbriae by the non-virulent strain F87 containing pJN99, a pACYC184-derived multicopy plasmid harbouring the K99 operon, at different $\mu$ values during growth in the chemostat. At $\mu=0.42 \mathrm{~h}^{-1}$, production was $6 \mu \mathrm{g} \mathrm{K} 99$ per ml culture $\left(\mathrm{OD}_{600}=1\right)$, while at $\mu=$ $0.2 \mathrm{~h}^{-1}$ it was less than $5 \%$ of this value. Quantitative plasmid isolation showed that the average plasmid content of the cells at $\mu=0.42 \mathrm{~h}^{-1}$ was approximately $50 \%$ of that at $\mu=0.2 \mathrm{~h}^{-1}$. Thus, production of $\mathrm{K} 99$ per operon copy at a high growth rate relative to a lower growth rate is even larger. The results indicated that the

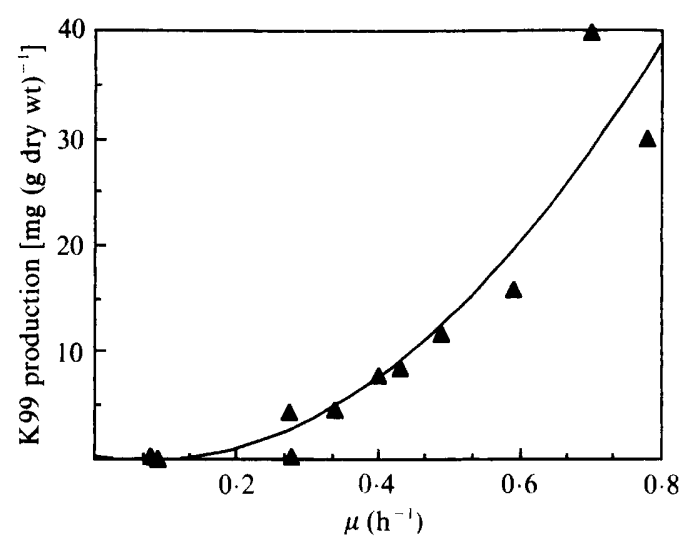

Fig. 2. Production of K99 fimbriae at different specific growth rates by $E$. coli strain F18 in continuous culture with sulphate as the growthlimiting nutrient.

regulatory mechanism involved in growth-rate-dependent $\mathrm{K} 99$ production also functioned with the cloned $\mathrm{K} 99$ operon, and that this phenomenon was independent of the K99 operon copy number. Also, the regulatory mechanism seems to be present both in the wild-type strain and in the non-virulent strain F87.

\section{Subunit synthesis as a function of the specific growth rate}

We aimed to examine the regulatory mechanism underlying the growth-rate-dependent synthesis of K99 fimbriae. Possibly, a limited intracellular concentration of fimbrial subunits decreased production of fimbriae at lower growth rates. Unfortunately, attempts to develop an ELISA specific for single subunits were unsuccessful, probably because the subunit has only one, predominant, antigenic determinant (F. G. van Zijderveld, personal communication).

A different approach was to examine whether the transcription of the operon was growth-rate-dependent. Firstly, we investigated the transcription of the fimbrial subunit gene at different growth rates. In plasmid pRR2, the expression of the gal $K$ gene is under direct control of the complete $\mathrm{K} 99$ regulatory region: promoter $\mathrm{P}_{\mathrm{A}}$, fan $A$, terminator $T_{1}$, promoter $P_{B}$, fan $B$ and terminator $T_{2}$ (Fig. 1; Roosendaal et al., 1989). The galK gene is fused to the subunit gene $(f a n C)$ so that the transcription of the galK gene, as determined by galactokinase activity, can be taken as a measure of fanC gene transcription. Because the fusion vector $\mathrm{pKO}-1$ carries the $\beta$-lactamase gene, the activity of this enzyme can be used as an indication of plasmid copy number (Klotsky \& Schwartz, 1987). The galactokinase activity was calculated per standard number of galK gene copies by dividing the galactokinase activity (U) by $\beta$-lactamase activity (U); these values are referred to as relative galactokinase 


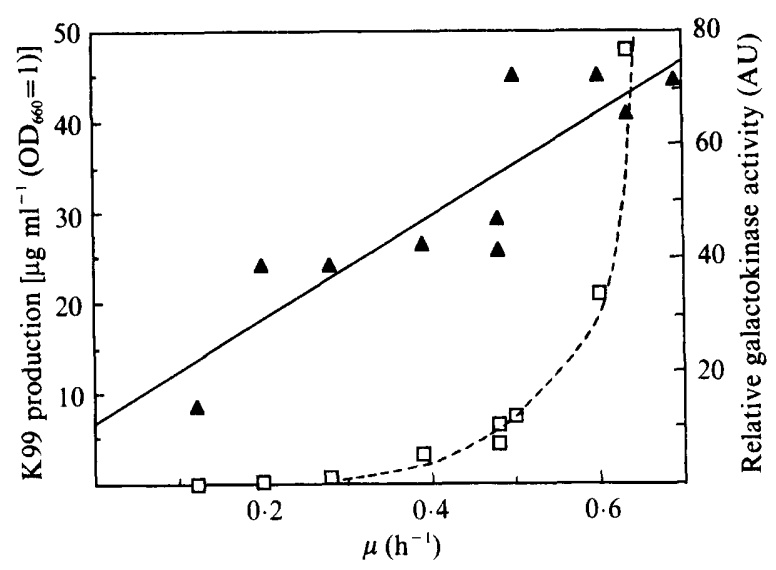

Fig. 3. K99 production $(\square)$ and relative galactokinase activity $(\boldsymbol{\Delta})$ of strain F18 harbouring plasmid pRR2 and grown in continuous culture at different specific growth rates with glucose as growth-limiting nutrient.

activity (AU). The background relative galactokinase activity of the vector without promoter insert (pKC86) in a galK strain growing at $\mu=0.36 \mathrm{~h}^{-1}$ in a chemostat was approximately $11 \mathrm{AU}(133 \mathrm{U}$ galactokinase; $12 \mathrm{U} \beta$ lactamase).

The wild-type, K99-producing strain F18 was transformed with plasmid $p R R 2$. The background galactokinase activity due to the chromosomal gal $K$ gene in strain F18 measured at $\mu=0.5 \mathrm{~h}^{-1}$ was less than $10 \mathrm{U}$. Values for strain F18(pRR2) were much higher: for example, $460 \mathrm{U}$ of galactokinase and $10 \cdot 5 \mathrm{U}$ of $\beta$-lactamase were measured at $\mu=0.48 \mathrm{~h}^{-1}$. Subsequently, relative galactokinase activity and $\mathrm{K} 99$ production were determined at different $\mu$ values with glucose as the growthlimiting nutrient (Fig. 3). The production of K99 fimbriae followed the pattern observed for cultures of strain F18 without pRR2; at $\mu$ values above approximately $0.3 \mathrm{~h}^{-1}$ an increase in production of fimbriae was observed with increasing $\mu$. Below $\mu=0.3 \mathrm{~h}^{-1}$ no $\mathrm{K} 99$ production could be measured. Furthermore, increasing $\mu$ correlated with increasing relative galactokinase activity. This suggested that in vivo an increase in transcription of the subunit gene $\operatorname{fan} C$ will take place at higher growth rates.

The galactokinase activity of $\mathrm{pRR} 2$ was also measured in a galK strain which produces no K99 fimbriae. The relative galactokinase activity pattern was similar to that obtained in strain F18 (results not shown).

\section{Promoter activity as function of the specific growth rate}

The increase in transcription rate of the subunit gene described above could be due to a regulatory mechanism influencing promoter activity at $P_{A}$ and/or $P_{B}$ or terminator efficiency at $T_{1}$ and/or $T_{2}$, or a combination

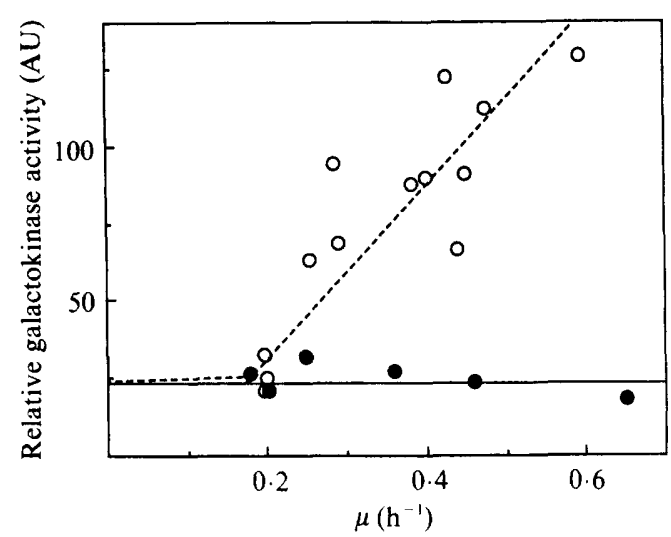

Fig. 4. Relative galactokinase activity of the galK strain harbouring pPA $(O)$ or pPB (O) and grown at different specific growth rates in continuous culture with glucose as growth-limiting nutrient.

of these effects. Possible regulation of promoter activity was tested by determining the relative galactokinase activity of the galK strain transformed by plasmids pPA and pPB (see Fig. 1), at different $\mu$ values (Fig. 4). The galactokinase activity controlled by promoter $\mathrm{P}_{B}$ remained constant at approximately $33 \mathrm{AU}$ at different $\mu$ values. Plasmid pPA, however, showed an increase in galactokinase activity with increasing $\mu$. This indicated an increase in transcription originating from promoter $\mathbf{P}_{\mathrm{A}}$. Both plasmids gave rise to galactokinase activities above the level resulting from the vector $\mathrm{pKC} 86$ without promoter insert (11 AU). All the $\mu$ values examined were lower than $0.7 \mu_{\max }$ and no glucose could be detected in supernatant fractions, indicating that the phenomena are not caused by catabolite repression.

\section{Discussion}

The regulatory mechanism underlying the previously reported growth-rate-dependent production of K99 fimbriae by enterotoxigenic $E$. coli (Van Verseveld et al., 1985) was examined by measuring K 99 production under different growth conditions as well as by determining the transcriptional regulation.

The growth-rate-dependent production of K99 fimbriae was similar with sulphate or glucose as the growthlimiting nutrient, indicating that growth rate regulation is independent of the nature of the growth-limiting nutrient.

E. coli K12 harbouring pJN99 with the cloned K99 operon also showed an increase of $\mathrm{K} 99$ production at higher growth rates, indicating that the cloned K99 operon contained all the genetic information necessary for growth-rate dependent production. No change in growth-rate-dependent K99 production was found when the cells contained an excess of the K99 regulatory 
region. This suggested that no hypothetical regulatory host factor, either a repressor or an activator of transcription, was titrated by the $\mathrm{K} 99$ regulatory region at lower or higher growth rates, respectively.

Transcriptional regulation was examined with galactokinase gene fusions. Expression of galK from its own promoter is independent of the growth rate (Duester et al., 1982), indicating that the stability of galK mRNA is not affected by the growth rate. Therefore, we assume that the variations in galactokinase activity found in galactokinase gene fusions were a direct reflection of regulatory mechanisms exerted by the DNA fragments inserted in the vector.

The expression of the gal $K$ gene in pPA increased with increasing growth rate, indicating an increase in transcription originating from promoter $\mathrm{P}_{\mathrm{A}}$. In contrast, the expression of the galK gene fused to $\mathrm{P}_{\mathrm{B}}$ was constant, indicating a constant activity of promoter $P_{B}$. On the basis of our results we cannot identify the mechanism that determines the growth-rate-dependent transcription of $P_{A}$. Also, we have no indications that either of the two well-known regulatory factors, ppGpp and cAMP, is involved. GC-rich sequence stretches and a $16 \mathrm{bp}$ stretch between the -10 and -35 region of the promoter have been implicated in growth-rate- and ppGpp-dependent stringent control of transcription (Lindahl \& Zengel, 1986; Deneer \& Spiegelman, 1987; Baracchini \& Bremer, 1988; Dickson et al., 1989). Such sequences are absent around the -35 and -10 region of promoter $P_{A}$ (Roosendaal et al., 1987a). The nucleotide sequence upstream from $P_{A}$ shows a high degree of homology with the consensus CAP-binding sequence and catabolite repression has been assumed to be involved in the regulation of K99 production (Ebright et al., 1984; Isaacson, 1980, 1983). Catabolite repression can take place in continuous cultures at high $\mu$ values $\left(>0.7 \mu_{\max }\right)$ (Bull, 1985). Our experimental data, however, indicated that catabolite repression was not involved in the growth-rate-dependent regulation. The transcription of $\mathrm{P}_{\mathrm{A}}$ was measured in glucose-limited continuous cultures at $\mu$ values that were always lower than $0.7 \mu_{\max }$ and consequently no catabolite repression takes place. Also, the expression of the gal $K$ gene in plasmid pPA was not affected by addition of external cAMP to a concentration of $5 \mathrm{mM}$ (unpublished results). Furthermore, K99 production by strain $\mathrm{F} 18$ was also measured in sulphatelimited continuous cultures with glucose in excess. This supports the idea that the growth rate regulation is not mediated by catabolite repression. Possibly, initiation of transcription at $\mathbf{P}_{\mathrm{A}}$ is regulated by the degree of supercoiling of the DNA (Higgins et al., 1988; Dorman et al., 1988; Dimri \& Das 1988; Léon et al., 1988) or the stability of mRNA transcribed from $P_{A}$ is affected by different rates of $5^{\prime}$ endonuclease activity, as has been found to regulate the growth-rate-dependent expression of ompA (Melefors \& Von Gabain, 1988; Nilsson et al., 1984).

The increase in galactokinase activity by strain F18 harbouring pRR2 could be interpreted as a linear rise as indicated in Fig. 3, but alternatively two levels of activity with a rise at $\mu=0.2 \mathrm{~h}^{-1}$ and $\mu=0.5 \mathrm{~h}^{-1}$ might be distinguished. If a linear relation exists between growth rate and transcription, our experimental approach gives rise to a large spread of the measured values (Fig. 3). Similar variations in K99 production levels have been found in different cultures under identical growth conditions (Van Verseveld et al., 1985). A linear increase in transcription of $f a n C$ as indicated by the galactokinase activity from pRR2 could be accounted for by the increase in transcription of $P_{A}$ (Fig. 4). Assuming two levels of galactokinase expression from pRR2 implicates a more complicated mechanism of transcriptional regulation.

A remarkable difference was observed between the pattern of increase of transcription of $\operatorname{fanC}$ and that of K99 production. This indicates that besides a growthrate-related increase in transcription also a post-transcriptional regulatory mechanism must be functioning. Since all K99 proteins (FanA-FanH) are essential for $\mathrm{K} 99$ biosynthesis, any of the many steps involved in this process may be a target for post-transcriptional regulation.

A likely hypothesis could be the growth-rate-related stability of a mRNA species or mRNA secondary structure. In this respect it should be mentioned that the transcript of the intercistronic region between fanC and fanD might fold into a hypothetical stem and loop structure (terminator $\mathrm{T}_{3}$ ) that contains the ribosomebinding site and possible start codon for FanD (Fig. 5). Uncoupling of transcription and translocation at low growth rate (Bremer \& Dennis, 1987) may allow the formation of this mRNA secondary structure, while the increase in ribosome concentration and higher rate of polypeptide chain elongation at high growth rate may have the reverse effect. An analogous mechanism of post-translational regulation of growth-rate-dependent gene expression has been described for the gnd structural gene of $E$. coli (Carter-Muenchau \& Wolf, 1989). Studying the levels and stability of mRNA in chemostat samples may give additional information about the growth-rate-dependent regulation of K99 synthesis.

Baecker et al. (1988) found evidence for a third promoter in the $\mathrm{K} 99$ gene cluster, located between $f a n D$ and $f a n E$. However, our nucleotide sequence data do not reveal any promoter sequence in this region (Roosendaal \& De Graaf, 1989).

Further research will be done to investigate which factors are involved in the transcriptional regulation at 


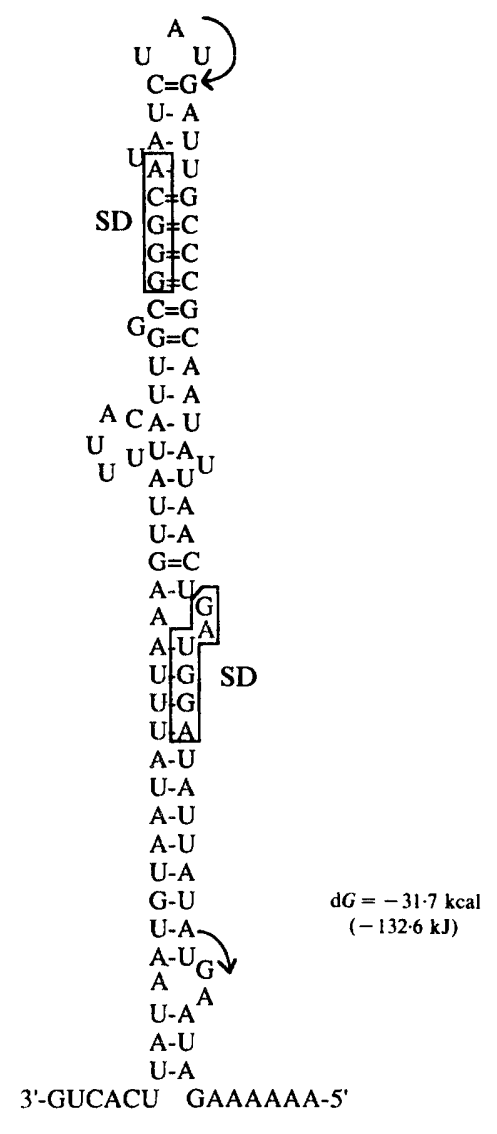

Fig. 5. Secondary structure of mRNA transcribed from the intercistronic region between $f a n C$ and $f a n D$ (predicted after Zucker \& Stiegler, 1981). The possible ribosome-binding (Shine-Dalgarno) sites (SD, boxes) and matching fanD start codons (arrows) are indicated.

$\mathrm{P}_{\mathrm{A}}$ and other mechanisms that regulate the synthesis of K99 fimbriae.

This investigation was supported by the Netherlands Foundation for Biological Research (BION) with financial aid from the Netherlands Organization for Scientific Research (NWO).

\section{References}

Baecker, P. A., Shelton, E. R., Bursztyn-Pettegrew, H., Salazar, F., Osen, E. G., Stoufer, S. D., Lee, S. W. \& Chan, H. W. (1988). Expression of $\mathrm{K} 99$ adhesion antigen controlled by the Escherichia coli tryptophan operon promoter. Infection and Immunity 56, 2317-2323.

BARACCHINI, E. \& BREMER, H. (1988). Stringent and growth control of rRNA synthesis in Escherichia coli are both mediated by ppGpp. Journal of Biological Chemistry 263, 2597-2602.

BREMER, H. \& DENNIS, P. P. (1987). Modulation of chemical composition and other parameters of the cell by growth rate. In Escherichia coli and Salmonella typhimurium, vol. 2, pp. 1527-1542. Edited by J. L. Ingraham, K. B. Low, B. Magasanik, M. Schaechter \& E. Umbarger. Washington, DC: American Society for Microbiology.
BuLl, A. T. (1985). Mixed culture and mixed substrate systems. In Comprehensive Biotechnology, vol. 1, pp. 281-299. Edited by M. MooYoung. Oxford: Pergamon Press.

Carter-Muenchau, P. \& Wolf, R. E., JR (1989). Growth ratedependent regulation of 6-phospho-gluconate dehydrogenase level mediated by an anti-ShineDalgarno sequence located within the Escherichia coli gnd structural gene. Proceedings of the National Academy of Sciences of the United States of America 86, 1138-1142.

CHAK, K-F. \& JAMES, R. (1985). Analysis of the promoter for the two immunity genes present in the ColE3-CA38 plasmid using two new promoter probe vectors. Nucleic Acids Research 13, 2519-2531.

De Graaf, F. K., Klaasen-Boor, P. \& Van Hees, J. E. (1980a). Biosynthesis of the $\mathrm{K} 99$ surface antigen is repressed by alanine. Infection and Immunity 30, 125-128.

de Graaf, F. K., Klemm, P. \& Gaastra, W. (1980b). Purification, characterization and partial covalent structure of Escherichia coli adhesive antigen K99. Infection and Immunity 33, 877-883.

De Graaf, F. K., Wientues, F. B. \& KlaAsen-Boor, P. (1980c). Production of K99 antigen by enterotoxigenic Escherichia coli strains of antigen groups $\mathrm{O} 8, \mathrm{O} 9, \mathrm{O} 20$ and $\mathrm{O} 101$ grown at different conditions. Infection and Immunity 27, 216-221.

De GraAf, F. K., Krenn, B. E. \& KlaAsen, P. (1984). Organization and expression of genes involved in the biosynthesis of $\mathrm{K} 99$ fimbriae. Infection and Immunity 43, 508-514.

Deneer, H. G. \& Spiegelman, G. B. (1987). Bacillus subtilis rRNA promoters are growth rate regulated in Escherichia coli. Journal of Bacteriology 169, 995-1002.

Dickson, R. R., GaAl, T., De Boer, H. A., De Haseth, P. L. \& GoURSE, R. L. (1989). Identification of promoter mutants defective in growth rate-dependent regulation of rRNA transcription in Escherichia coli. Journal of Bacteriology 171, 4862-4870.

DimRI, G. P. \& DAS, H. K. (1988). Transcriptional regulation of nitrogen fixation genes by DNA supercoiling. Molecular and General Genetics 212, 360-363.

Dorman, C. J., BarR, G. C., Ni Bhriain, N. \& Higgins, C. F. (1988). DNA supercoiling and the anaerobic and growth phase regulation of tonB gene expression. Journal of Bacteriology 170, 2816-2826.

DUESTER, G., Elford, R. M. \& Holmes, W. M. (1982). Fusion of the Escherichia coli tRNA leu promoter to the galK gene: analysis of sequences necessary for growth rate-dependent regulation. Cell 30 , 855-864.

Ebright, R. H., Cossart, P., Gicquel-Sanzey, B. \& Beckwith, J. (1984). Mutations that alter the DNA sequence specificity of the catabolite gene activator protein of E. coli. Nature, London 311, 232235.

Gaastra, W. \& De Graaf, F. K. (1982). Host-specific fimbrial adhesins of noninvasive enterotoxigenic Escherichia coli strains. Microbiological Reviews 46, 129-161.

Girardeau, J. P., Dubourguier, H. C. \& Gouet, Ph. (1982). Inhibition of K99 antigen synthesis by L-alanine enterotoxigenic Escherichia coli. Journal of General Microbiology 128, 463-470.

Higgins, C. F., Dorman, C. J., Sterling, D. A., Waddell, L., BOOTH, I. R., MAY, G. \& BREMER, E. (1988). A physiological role for DNA supercoiling in the osmotic regulation of gene expression in $S$. typhimurium and E. coli. Cell 52, 569-584.

ISAACSON, R. E. (1980). Factors affecting expression of the Escherichia coli pilus K99. Infection and Immunity 28, 190-194.

ISAACSON, R. E. (1983). Regulation of expression of Escherichia coli pilus K99. Infection and Immunity 40, 633-639.

KLOTSKY, R.-A. \& SCHWARTZ, I. (1987). Measurement of cat expression from growth rate regulated promoters employing $\beta$ lactamase activity as an indicator of plasmid copy number. Gene 55, 141-146.

Léon, P. G., Alvarez, G., Diaz de Léon, F. \& Gomez-Eichelmann, M. C. (1988). Effect of DNA supercoiling and catabolite repression on the expression of the tetA genes in Escherichia coli. Canadian Journal of Microbiology 34, 839-842.

LINDAHL, L. \& ZENGEL, J. M. (1986). Ribosomal genes in Escherichia coli. Annual Review of Genetics 20, 297-326.

Maniatis, T., Fritsch, E. F. \& Sambrook, J. (1982). Molecular Cloning, a Laboratory Manual. Cold Spring Harbor, NY: Cold Spring Harbor Laboratory. 
McKenney, K., Shimataku, H., Court, D., Schmeisser, U., Brady, C. \& Rosenberg, M. (1981). A system to study promoter and terminator signals recognized by Escherichia coli RNA polymerase. In Gene Amplification and Analysis, Analysis of Nucleic Acids by Enzymatic Methods, vol. 2, pp. 383-415. Edited by J. C. Chirikjian \& S. Papas. Amsterdam: Elsevier.

Melefors, Ö. \& Von Gabain, A. (1988). Site-specific endonucleolytic cleavages and the regulation of stability of E. coli ompA mRNA. Cell $52,893-901$

Nilsson, G., Belasco, J. G., Cohen, S. N. \& Von Gabain, A. (1984) Growth rate-dependent regulation of mRNA stability. Nature, London 312, 75-77.

O'Callaghan, C. H., Morris, A. \& Kirby, S. M. (1972). Novel method for detection of $\beta$-lactamase by using a chromogenic cephalosporin substrate. Antimicrobial Agents and Chemotherapy 1 , 283-288.

RoOsendaAl, B. \& De GraAF, F. K. (1989). The nucleotide sequence of the $f a n D$ gene encoding the large outer membrane protein involved in the biosynthesis of K99 fimbriae. Nucleic Acids Research 17, 1263.

Roosendali. E., Gaastra, W. \& De Graaf, F. K. (1984). The nucleotide sequence of the gene encoding the K99 subunit of enterotoxigenic Escherichia coli. FEMS Microbiology Letters 22, 253258

Roosendaal, E., Boots, M. \& De Graaf, F. K. (1987a). Two novel genes, $\operatorname{fan} A$ and $\operatorname{fan} B$ involved in the biogenesis of $\mathrm{K} 99$ fimbriae. Nucleic Acids Research 15, 5973-5984.
Roosendal, E., Jacobs, A. A., Rathman, P., Sondermeyer, C., Stegehuis, F., Oudega, B. \& De Graaf, F. K. (1987b). Primary structure and subcellular localization of two fimbrial subunit-like proteins involved in the biosynthesis of K99 fibrillae. Molecular Microbiology 1, 211-217.

Roosendaal, B., Damoiseaux, J., Jardi, W. \& De Graaf, F. K. (1989). Transcriptional organization of the DNA region controlling expression of the K99 gene cluster. Molecular and General Genetics 215, 250-256.

Stouthamer, A. H. \& Bettenhausen, C. W. (1975). Determination of the efficiency of oxidative phosphorylation of continuous cultures of Aerobacter aerogenes. Archives of Microbiology 102, 187-192.

Van Embden, J. D. A., De GraAf, F. K., Schouls, L. M. \& Teppema, J. S. (1980). Cloning and expression of a deoxyribonucleic acid fragment that encodes for the adhesive antigen K99. Infection and Immunity 29, 1125-1153.

Van Verseveld, H. W., Bakker, P., Van Der Woude, T., Terleth, C. \& DE GraAf, F. K. (1985). Production of fimbrial adhesins K99 and F41 by enterotoxigenic Escherichia coli as a function of growth rate domain. Infection and Immunity 49, 159-163.

ZUCKER, M. \& STIRGLER, P. (1981). Optimal computer folding of large RNA sequences using thermodynamics and auxiliary information. Nucleic Acids Research 9, 133-148. 